Proceedings

\title{
Sustainable Built Environment in Kazakhstan: The Way towards Better IAQ ${ }^{+}$
}

\author{
Aigerim Uyzbayeva \\ Laboratory of Green Energy and Environment, "National Laboratory Astana" Private Institution, \\ Astana 010000, Kazakhstan; aigerim.uyzbayeva@nu.edu.kz; Tel.: +7-7172-70-92-76 \\ + Presented at the Economy, Sustainable Development and Energy International Conference (ESDEIC), \\ Edinburgh, Scotland, UK, 25-27 June 2018.
}

Published: 6 November 2018

\begin{abstract}
The fast economic growth, an expanding population and high standards of living required by people has led to increase not only in the urban energy demand but also strengthened the relation between cities, health and the environment. Kazakhstan is currently one of the dynamically developing countries in its region and is experiencing the stable growth in all sectors of the economy which is highly dependent on traditional energy sources like coal, oil and gas. To reduce the energy demand and consumption by the different industrial sectors, Kazakhstan targets shifting towards the sustainable use of the resources through implementing the low-carbon strategies construction sector as well. Sustainable development is a broad topic that outlines 17 goals and to achieve the sustainability in buildings it is vital to consider the relationship between occupants and their living habitat. This paper shortly provides an overview of the energy efficiency situation in Kazakhstan examines the factors affecting sustainable built environment such as indoor air quality.
\end{abstract}

Keywords: sustainable buildings; radon in Kazakhstan; indoor air quality; energy efficiency in Kazakhstan

\section{Introduction}

The fast economic growth worldwide, an expanding population and high standards of living required by people has led to increase not only in the urban energy demand but also strengthened the relation between cities, health and the environment. The global energy consumption is expected to rise by 35 percent compared to 2010 as the world's population reaches 9 billion people by 2040 [1]. Likewise, the average rate of annual urbanization in Kazakhstan currently stands at $0.9 \%$ and urban inhabitants are expected to reach $66.3 \%$ of the country's population by 2030 [2]. Kazakhstan is currently one of the dynamically developing countries in its region and is experiencing the stable growth in all sectors of the economy which is highly dependent on traditional energy sources like coal, oil and gas. As well as consuming the huge amount of energy sources, the country emits greenhouse gases (GHG) and is the third largest emitter in Eurasia [3]. It is estimated that $80 \%$ of GHG pollution in the Republic of Kazakhstan comes from the energy sector, ninety percent of which are generated by energy and power production sector. With the ambitious aim to transit to "green economy" the country's major challenge and urgent need is the diversification of energy base and reduction of GHG emissions by improving energy efficiency in all economy sectors. To reduce the energy demand and consumption by the different industrial sectors, Kazakhstan targets shifting towards the sustainable use of the resources through implementing the low-carbon strategies in construction sector as well. 


\section{Current Situation of Sustainable Built Environment}

\subsection{Buildings}

Among different elements of urban built environment, buildings deserve particular attention due to their large contribution to environmental and health problems. The concept of sustainable building is a recent response to address the problems that stem from the building sector [4]. Currently, Kazakhstan is experiencing the massive growth of construction structures to meet the housing demand. Since the beginning of the 2000s, the construction market in Kazakhstan is raised rapidly despite the economic crisis back in 2007 and is continuing to grow. The construction activities dynamics of Kazakhstan is shown in Figure.1.

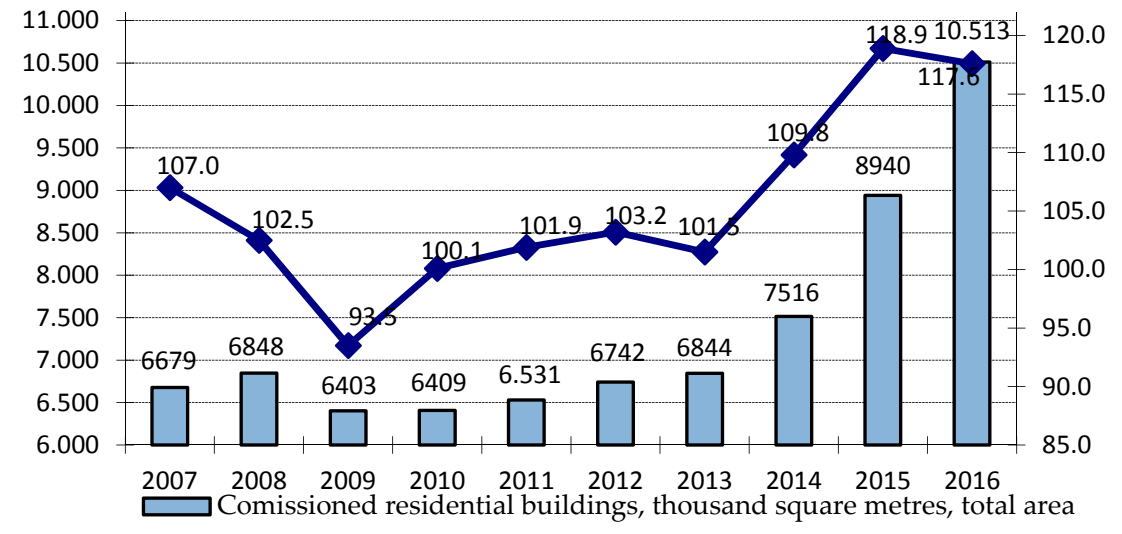

Figure 1. Dynamics of the main indicators of construction activities in Kazakhstan [5].

\subsection{Existing Policies and Projects}

There are different policies and projects being implemented in industrial and economic sectors of Kazakhstan towards the environmental sustainability (Table 1). A range of green technologies, including roof solar system, such as photovoltaic panels, solar thermal with heat pumps for HVAC system, wind turbines and waste management were introduced to implement sustainable development principles in the built environment, especially residential buildings.

Table 1. Existing policies and projects.

\begin{tabular}{|c|c|}
\hline Existing Policies & Implemented Projects \\
\hline 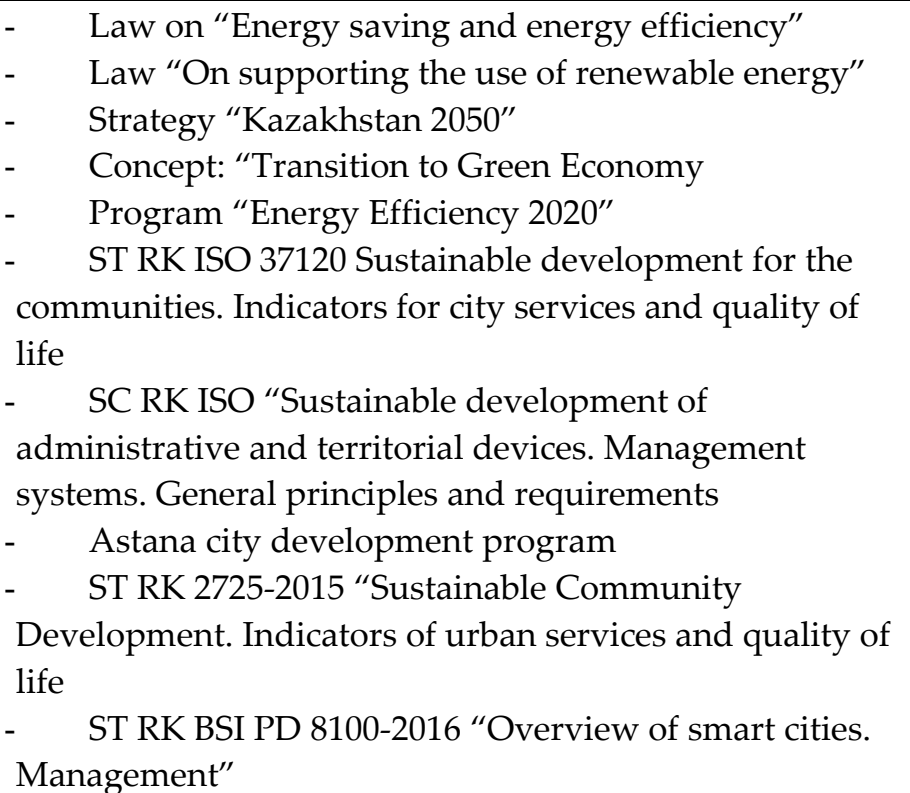 & $\begin{array}{l}-\quad \text { UNDP-GEF Projects On Energy } \\
\text { Efficiency } \\
-\quad \text { Removing barriers to energy } \\
\text { efficiency in municipal heat and hot } \\
\text { water supply } \\
-\quad \text { Green Quarter project } \\
-\quad \text { Energy City Villas } \\
-\quad \text { Solar City Villas } \\
-\quad \text { Sustainable Cities for } \\
\text { Low-Carbon Development project } \\
-\quad \text { LEED Certified: Talan Towers } \\
\text { Office Building } \\
-\quad \text { BREEAM Certified: Park View } \\
\text { Office Building }\end{array}$ \\
\hline
\end{tabular}




\subsection{Indoor Air Quality}

It should be mentioned that the sustainability concept of the built environment also reflects in occupant satisfaction as by energy bills so by indoor air quality as well. The results of national energy audit of old building sector has indicated that energy use can be reduced up to 30\% through implementing a package of measures to upgrade the energy efficiency of an existing housing stock. While maintaining comfortable indoor air temperature in winter and increasing air tightness of the envelope is good for energy efficiency it has a potential to increase the concentrations of various harmful pollutants, in particular if the ventilation is not controlled. Although the new buildings are developed in accordance with local energy efficient standards, they still exert considerable impact on the natural environment. According to the IEA buildings represent the $40 \%$ of primary energy use globally and the existing buildings are responsible for 24 percent of global CO2 emissions [6,7]. Along with GHG emissions, building sector is also responsible for health and wellbeing issues in cities [8]. Scientific sources indicate that people spend $80-90 \%$ of their lives in confined spaces such as homes, office buildings and schools/universities with a limited air exchange rate and access to the fresh air. It is known that poor indoor air quality can result in diseases like cancer, sickness and generally affect the general performance. Moreover, in developing countries people tend to live in low-quality buildings that are highly vulnerable to adverse environmental impacts due to being located on hazardous sites.

The current legislation documents of Kazakhstan set the requirements to only certain indoor air characteristic like temperature, humidity, acoustic control but do not pay attention to indoor $\mathrm{CO}^{2}$ emissions and radon concentration level. According to the World Health Organization, radon and its derivatives are in the second biggest threat after smoking in terms of lung cancer risk, responsible for some $15 \%$ of lung cancers worldwide. Radiation Safety Standards of Kazakhstan set a limitation $200 \mathrm{~Bq} / \mathrm{m}^{3}$ for radon concertation in existing buildings and $100 \mathrm{~Bq} / \mathrm{m}^{3}$ for newly developed buildings [9]. However, there are no continuous and additional measurements taken during the lifetime of residential buildings which leave people exposed to indoor radon. The substantial amount of indoor radon study activities has been employed in the country by "Ecoservice-C", LLP. For example, more than 3300 low-rise dwellings have been studied in 26 regions and their villages in Kazakhstan. The study results showed that the floors made of concrete and wood mainly corresponding to $5.1 \%$ and $94.9 \%$ respectively. Out of the 3154 dwellings with wooden floors at 367 houses or $11.6 \%$ high level of radon reaching up to $2000 \mathrm{~Bq} / \mathrm{m}^{3}$ has been registered while according to the Radiation Safety Standards of Kazakhstan the limitation for radon concertation in operating buildings should be 10 times less. As for the houses with concrete floors in 34 houses out of 170, indoor radon concentration was determined [10].

\section{Discussion}

To improve the IAQ in existing and projected buildings mechanical ventilation should be applied. However, according to the Kazakhstan building codes and standards, the controlled ventilation is only applicable for the administrative, office, school, health and other type of buildings except residential [11]. Which means the mitigation of radioactive and non-radioactive contamination of indoor air is already not possible in residential dwellings unless special technical solutions are installed. The local building codes and standard should be changed and updated on better IAQ and radon mitigation measures. The mechanical ventilation should be introduced as a necessity for fresh air at the buildings with efficient airtight envelope. There is no doubt that comparing to the conventional dwellings the buildings with the greater energy efficiency features have the potential to not only minimize the negative impact on the environment and offer to an occupant health related benefits and help the country to meet its sustainability goals.

Acknowledgments: This paper is developed as a part of research project №144-2018//010-2018 “Assessing the impact of ventilation systems on the concentration of radon in buildings in Kazakhstan" carried out at the Laboratory of Green Energy and Environment of National Laboratory Astana, Private Institution. 
Conflicts of Interest: The authors declare no conflict of interest

\section{References}

1. ExxonMobil. The Outlook for Energy: A View to 2040; ExxonMobil: Irving, TX, USA, 2013

2. Sustainable Cities: Rapid Urbanisation and Sustainability in Kazakhstan-Exploring the Use of Novel Technologies and Research Methods to Address Environmental and Social Change; Sustainable Cities Workshop: Astana, Kazakhstan, 2015.

3. UN Department of Economy and Social Affairs, 2014 Revision of the World Urbanisation Prospects. Available online: http://www.un.org/en/development/desa/publications/2014-revision-worldurbanization-prospects.html (accessed on 31 October 2018).

4. Mohtashami, N.; Mahdavinejad, M.; Bemanian, M. Contribution of City Prosperity to Decisions on Healthy Building Design: A case study of Tehran. Front. Arch. Res. 2016, 5, 319-331.

5. Statistics Agency. Dynamics of the Main Indicators of Construction Activities in Kazakhstan; Statistics Agency: Astana, Kazakhstan, 2018.

6. IEA Statistics. Available online: http://www.iea.org/statistics/statisticssearch/report/?year=2012\&country= Kazakhstan\&product=ElectricityandHeat (accessed on 31 October 2018).

7. IEA. Key World Energy Statistics. $2014 . \quad$ Available online: http://www.iea.org/publications/freepublications/publication/keyworld2014.pdf (accessed on 31 October 2018).

8. Balaban, O.; de Oliveira, J.A. Sustainable buildings for healthier cities: assessing the co-benefits of green buildings in Japan. J. Clean. Prod. 2017, 163, S68-S78.

9. Ministry of Energy, Ecological Code of the Republic of Kazakhstan.

10. Uyzbayeva, A.; Ibrayev, N.; Sharipova, D. Influence of the Building Envelope and Ventilation on Indoor Radon Concentration: Review of the Measurement Results in Low-Rise Dwellings Kazakhstan. 2017. Unpublished.

11. Ministry of Health of RK, Sanitary-Epidemiological Requirements to the Maintenance and Operation of Residential and Other Premises Public Buildings

(C) 2018 by the author. Licensee MDPI, Basel, Switzerland. This article is an open access article distributed under the terms and conditions of the Creative Commons Attribution (CC BY) license (http://creativecommons.org/licenses/by/4.0/). 